\title{
Nilai Ekonomi Umbul Pengging Sebagai Area Tujuan Wisata
}

\author{
Sri Walyoto \\ IAIN Surakarta, Indonesia \\ Walyoto_Colomadu@yahoo.co.id
}

\begin{abstract}
This research was conducted to determine the consumer surplus and total economic value of the Sharia Umbul Pengging tourist destination in Dukub Village, Banyudono District, Boyolali Regency, Central Java Province, Indonesia. The area is a natural area as a public water source managed by the local government. The main objective of this study was to analyze the demand of Umbul Pengging as a sharia tourist destination. The Travel Cost Method (TCM) is used to estimate the travel demand offered by Umbul Penggging. The evaluation approach used service preferences expressed from the point of view of the user of the Umbul Pengging dominant function. The collected data produces a tourist request function Umbul Pengging is formulated as a function of travel costs, sacrifice of travel time and income and visitor education. The results of research on travel costs, income and education of visitors are significant, tourists get benefits (surplus) for their visits.
\end{abstract}

Keywords: Sharia Tourism, Umbul Pengging, TCM, Request Function.

\begin{abstract}
Abstrak
Penelitian ini dilaksanakan untuk mengetahui surplus konsumen serta nilai ekonomi secara total destinasi wisata syariah Umbul Pengging Desa Dukuh Kecamatan Banyudono Kabupaten Boyolali Propinsi Jawa Tengah-Indonesia. Area tersebut merupakan daerah alami sebagai sumber airpublikyang dikelolapemerintah daerah. Tujuan utamapenelitian ini untuk menganalisis permintaan Umbul Pengging sebagai destinasi wisata syariah. Model biaya perjalanan/Travel Cost Method (TCM) digunakan untuk memperkirakan permintaan wisata yang ditawarkan Umbul Penggging. Pendekatan evaluasi digunakan preferensi layanan yang diungkapkan dari sudut pandang pengguna fungsi dominan Umbul Pengging. Data yang dikumpulkan menghasilkan fungsi permintaan wisata Umbul Pengging dirumuskan sebagai fungsi dari biaya perjalanan, pengorban waktu perjalanan dan pendapatan serta pendidikan pengunjung. Hasil penelitian menunjukkan babwa biaya perjalanan, pendapatan dan pendidikan pengunjung signifikan, wisatawan memperoleh manfaat (surplus) atas kunjungannya.
\end{abstract}

Kata Kunci: Wisata Syariah Umbul Pengging, TCM, Fungsi Permintaan.

Permalink/DOI: http://dx.doi.org/10.18326/infsl3.v13i1.99-126 


\section{Pendahuluan}

Daerah pariwisata merujuk tempat-tempat lingkungan dengan, layanan dan fasilitas yang memungkinkan orang untuk melakukan kegiatan berwisata yang memberikan kenikmatan. Tempat wisata yang biasanya terdiri dari berbagai lanskap, fauna dan flora yang sesuai untuk kegiatan wisata. Saat ini, di Indonesia telah banyak didibangun area-area untuk tujuan wisatawan seperti Umbul Pengging. Dengan fasilitas yang tersedia, umbul ini menawarkan berbagai kegiatan wisata seperti berenang, olah raga, kuliner, memancing manikmati udara segar. Wisata syariah perlu mendapat perhatian dan perlu dikembangkan di daerah-daerah tujuan wisata.

Pembangunan pariwisata tidak bisa dipisahkan dengan pembangunan ekonomi. Ekonomi Islam saat ini menjadi bagian penting dari okonomi global sektor pariwisata juga telah diatur batasan-batasannya oleh Islam (Rahmi, 2014). Sektor ekonomi Islam yang sedang berkembang antara lain keuangan Islam, asuransi, kuliner, kosmetik, fashion, hiburan, promosi dan pariwisata. Ekonomi Islam Islam selalu mengetengahkan konsep halal hal ini juga perlu menjadi perhatihan dalam mewujudkan wisata halal. Ada tiga ukuran wisata halal yaitu, terciptanya destinasi ramah keluarga, tersedianya fasilitas dan layanan di destinasi ramah muslim serta adanya kesadaran halal dalam pemasaran destinasi.

Pariwisata menjadi adalan utama sumber devisa karena Indonesia merupakan salah satu negara yang memiliki beraneka ragam pariwisata (Helln, 2017). Industri pariwisata di Indonesia seperti banyak tetangganya (Malaysia, Thailand dan Singapura) merupakan salah satu subsektor ekonomi terbesar dalam hal pekerjaan, PDB kontribusi dan penerimaan devisa. Pada tahun 2017 indonesia berada pada rangking ketiga sebagai destinasi wisata halal. Berbasis alam dan budaya-warisan pariwisata khususnya telah lama menjadi komponen utama dari industri pariwisata dan perhotelan di dalam negeri. Atraksi seperti tidak diragukan lagi merupakan perwujudan dari sejarah negara yang dinamis serta kaya keanekaragaman alam dan budayanya.

Partisipasi masyarakat di suatu daerah dapat mencerminkan fungsi sosialnya sebagai area wisata syariah. Nilai dari daerah 
dapat memberikan manfaat wisatawan yang selama ini belum diperhitungkan. Ekonom lingkungan telah mengembangkan klasifikasi nilai yang tersimpan oleh perilaku di mana orang memperoleh manfaat atas penggunaan lingkungan. Manfaat ini diperoleh secara langsung sementara yang lain diperoleh secara tidak langsung (Mc. Nally \& Shawahid 2003).

Ada kesepakatan umum bahwa pariwisata dapat memainkan peran kunci dalam melestarikan keanekaragaman alam dan budaya-warisan yang kaya di seluruh dunia melalui promosi pembangunan pariwisata berkelanjutan. Namun, prasyarat penting untuk memastikan seperti pengembangan pariwisata syariah adalah ketersediaan dana yang memadai untuk konservasi dan pemeliharaan. Memang, kurangnya dana telah menjadi karakteristik umum dan pengelolaan kawasan lindung di negara berkembang.

Pemerintah Indonesia telah mengembangkan duadelas destinasi wisata syariah yaitu Lampung, Aceh, Riau, Sumatra Barat, Jawa Barat, Jakarta, Banten, Yogyakarta, Jawa Timur, Sulawesi Selatan, Nusatenggara Barat dan Jawa Tengah. Pariwisata syariah menjunjung tinggi budaya dan nilai-nilai Islam. Persepsi yang ada saat ini hanya sebagai wisata ke makam atau masjid. Perlu adanya perluasan persepsi dimana wisata syariah juga berasal dari alam, budaya maupun buatan yang bernuansa islami dan fasilitas pendukung yang halal beruansa etika syariah. Wisata syariah merupakan suatu tren baru dalam dunia pariwisata saat ini (Ade, 2016).

Pariwisata merupakan salah satu sektor untuk memperoleh pendapatan daerah (Setiawan 2016). Pariwisata serta daerah wisata dianggap sebagai sumber daya yang memiliki nilai. Nilai diperoleh atas penggunaan langsung oleh manusia dari sumber daya tersebut dalam pariwisata. Nilai barang dan jasa non pasar harus diukur dan dinyatakan dalam istilah keuangan. Sehingga dapat ditimbang pada skala yang sama sebagai komponen komersial barang yang diperdagangkan (Eliot, 2001). Pengembangan potensi wisata Syariah di Indoneisia dengan memperhatikan aspek wisatawan Timur Tengah sebagai pasar sasaran utama wisatawan manca negara (Kurniawan, 2015). 
Dalam rangka mengevaluasi peran pariwisata syariah sebagai penggunaan lahan dan perkiraan kuantitatif harus diterapkan dalam pariwisata. Perkiraan kuantitatif permintaan pariwisata akan membantu dalam mengalokasikan sumber daya lebih efisien, dalam menentukan nilai relatif dari sumber daya yang digunakan untuk tujuan tersebut. Dalam membuat penilaian dampak ekonomi, membangun skema harga, pengambilan keputusan manajemen, dan dalam menentukan waktu akuisisinya (Ahmad 1994).

Umbul Pengging adalah salah satu tempat pariwisata di Desa Dukuh Kecamatan Banyudono Kabupaten Boyolali Propinsi Jawa Tengah. Umbul terserbut di bawah pengelolaan Dinas Pariwisata Kabupaten Bolayali. Umbul Pengging ini persinya terletak di Dusun Dukuh. Umbul pengging menawarkan berbagai kegiatan pariwisata di luar ruangan seperti memancing, berkemah, berenang, olah raga tenes, kuliner, menikmati udara segar, dengan dukungan layanan dan fasilitas yang disediakan oleh pemerintah daerah dan perbaikan-perbaikan yang syariah.

Kegiatan wisata di luar ruangan di Umbul Pengging sudah berlangsung sejak keraton Mataram Islam Surakarta Hadiningrat berkuasa. Maka umbul Penggging juga dapat masuk dalam benda cagar budaya. Hampir semua pengunjung yang datang di Umbul pengging sedang mencari keuntungan pribadi dan kepuasan dari kegiatan yang mereka lakukan. Selama ini tidak ada penelitian untuk mengukur kepuasan atau manfaat bagi pengunjung tersebut. Penelitian ini diperlukan karena akan membantu lembaga manajemen untuk memahami manfaat yang diperoleh pengunjung dari keberadaan umbul tersebut. Dengan demikian, studi ini dilakukan untuk menilai permintaan Umbul Pengging sebagai area pariwisata dan untuk memperkirakan nilai ekonominya.

Wisata syariah menjadi segmen baru yang sedang berkembang di dunia. Wisata islami dan motivasi rohani telah menyebar luas dan menjadi populer dalam beberapa dekade terakhir (Aan, 2017). Pariwisata merupakan sektor industri yang berkembang pesat di dunia. Word Tourism Barometer menunjukkan peningkatan pariwisata internasional. Pertumbuhan wisatawan terjadi di kawasan Asia, Pasifik, Afrika, Amerika Tengah, Asia Utara - Timur, dan 
Amerika Selatan. Industri Pariwisata memberikan sumbangan yang signifikan kepada pertumbuhan ekonomi melalui bidang-bidang usaha didalamnya seperti angkutan udara, hotel, makanan, agen perjalanan. Pariwisata merupakan sektor unggulan yang diharapkan mampu menggerakkan roda perekonimian (Maulana, 2016).

Dalam industri pariwisata terdapat berbagai daya tarik atau atraksi pariwisata yang menjadi daya tarik orang untuk mengunjungi suatu daerah tertentu. Dalam beberapa literature produk atau daya tarik alam, budaya dan minat khas (Musanef, 1995). Soekadijo (1996) mengelompokkan kedalam modal dan potensi alam, kebudayaan dan manusia. Alam disini dimaksudkan adalah alam fisik, hewan dan tumbuhan. Minat wisatawan untuk wisata eko disebabkan oleh aktivitas yang dapat dilakukan di alam terbuka. Harapan yang ingin dicapai wisata syariah dapat memenuhi keinginan dan kesenangan serta mendorong kesadaran beragama.

Yoeti (1996) membedakan menjadi produk alam, produk ciptaan manusia dan tata cara hidup masyarakat. Di Indonesia terdapat banyak tempat-tempat wisata eko yang dikembangkan berdasarkan lima prinsip utama, yaitu keislaman, konservasi, pendidikan, ekonomi, keterlibatan masyarakat setempat dan pariwisata (Departemen Kebudayaan dan Pariwisata 2005). Pengembangan pariwisata menurut Alisjahbana (2000) pertama perlu adanya multisektoral (seperti perhubungan, perhotelan, agen travel) kedua perlu memperhitungkan kesepakatan budaya dan alam sekitar. Ketiga juga diperlukan adanya potensi masyarakat setempat.

Pariwisata sebagai aktivitas manusia, merupakan pergerakan manusia, barang, dan jasa yang sangat komplek. Dapat mengenal ciptaan Nya serta kebudayaan yang beraneka. Sebaimana firman Allah SWT dalam surah Al-'Ankabut 19-20, dimana manusia perlu mengadakan perjalanan sgingga Pariwista berhubungan dengan organisasi, kelembagaan dan individu, pelayanan dan sebagainya. Ia memerlukan layanan penginapan semua ini merupakan rangkaian elemen yang saling mempengaruhi sehingga pariwisata dapat berjalan dengan baik. Kaitan atar elemen secara kuat yang 
kemudian menjadi suatu sistem yang disebut dengan sistem pariwisata.

Sistem pariwisata menurut Cooper et al (1996) memiliki tiga elemen penting yaitu wisatawan, geografi dan industri pariwisata. Geografi dapat dikelompokkan dalam tiga bagian yang diciptakan wisatawan atau pengembara (traveller-generating region), bagian tempat tujuan wisatawan (tourist destination region) dan bagian perpindahan (transit route region). Dalam pengembangan pariwisata syariah komponen penting attraction, amenities serta acsess oleh Herwawan Kertajaya dikenal dengan 3A perlu menjadi perhatian agar target tercapai.

Pariwisata syariah dari segi ekonomi dapat dilihat dalam empatunsuryaitu: permintaan, penawaran, pasardan kelembagaan, serta pelaku yang menggerakkannya. Menurut Damik dan Weber (2006) faktor yang mempengaruhi permintaan pariwisata adalah ketersediaan sumber waktu dan sumber kemampuan untuk mengakses pariwisata, pendapatan, dan distribusi pendapatan masyarakat, pendidikan masyarakat. Semakin tinggi Pendidikan wawasannya semakin luas keinginan untuk mempelajari sesuatu juga meningkat. Selain itu penghargaan terhadap tempat dan budaya yang berbeda juga semakin tinggi. Hal tersebut membuatnya semakin kuat untuk berwisata.

Penawaran pariwisata syariah adalah berupa produk dan jasa yang dapat digunakan dan memberikan kepuasan spiritual pada wisatawan. Menurut Damanik dan Weber (2006) beliu memandang elemen penawaran pariwisata terdiri dari atraksi, aksesibilitas (ke sampaian) dan amenitas (kemudahan). Atraksi adalah seluruh potensi pariwisata yang dapat memberikan kenikmatan wisatawan. Aksesibilitas meliputi keseluruhan infrastrukturyang menghubungkan wisatawan pergi balik dari tempat asal wisatawan. Amenitas adalah infrastruktur tidak langsung yang dipelukan oleh wisatawan.

Menurut Santosa (2002) perkembangan pariwisata Indonesia selain meningkatkan dan memberi sumbangan yang signifikan pada perekonomian, juga tertarik pada budaya, sejarah serta eko wisata. Perubahan keinginan wisatawan itu perlu diikuti berbagai strategi pengembangan pariwisata syariah baik pemerintah 
maupun pelaku agen-agen wisata agar indutri pariwisata syariah dapat berkembangan. Seperti diadakannya Deklarasi Bali 14 Juli 2000 bahwa budaya dan warisan adalah bagian dalam pariwisata yang perlu dilestarikan untuk pencapaian tujuan pembangunan pariwisata, ekonomi dan sosial yang berkelanjutan.

Kesadaran masyarakat dunia tetang pembangunan berkelajutan dimulai tahun 1992 sejak diadakan Konferensi bumi di Rio de Janeiro Brazil, pembangunan berkelanjutan diterima sebagai agenda politik pembangunan di dunia. Agenda utama pembangunan berkelanjutan adalah selarasnya ekonomi, sosial budaya dan lingkungan. Pemikiran ini merubah cara berpikir pembangunan yang hanya tersentral bidang ekonomi, menjadi pembangunan yang berorientasi ekonomi sosial budaya keagamaaan dan lingkungan.

Penjelasan Keraf (2006) ada tiga prinsip utama dalam pembangunan berkelanjutan, yaitu demokrasi, keadilan dan berkenjutan. Demokrasi, pembangunan menjamin terlaksananya keinginan rakyat untuk kepentingan bersama. Aspek penting dalam demokrasi pembangunan demi kepentingan rakyat, partisipasi masyarakat dalam menyusun kebijakan pembangunan dan implementasinya. Juga perlu ada informasi yang jujur dan terbuka serta adanya tanggung jawab masyarakat terhadap etika keislaman dalam agenda pembangunan.

Prinsip keadilan dimana bersedia menjamin semua orang mendapat kesempatan yang sama dalam proses dan menikmati hasil pembangunan. Sebagimana ajaran Islam yang menyatakan kesetaraan umat. Untuk memenuhi rinsip ini perlu ada berbagai tuntutan dan perlakuan peluang yang sama bagi generasi akan datang. Juga adanya pembagian kerugian akibat pembangunan yang seimbang baik negara ataupun kelompok yang menimbulkan kerugian tersebut. Pembangunan berkelanjutan mengharuskan menyusun agenda pembangunan dalam dimensi waktu jangka panjang.

Menurut Safri (2003) pembangunan berkelanjutan adalah pembanguan yang dapat memenuhi keperluan sekarang dan waktu akan datang segi fisik sosial ekonomi. Dalam pariwisata syariah yang dimaksud pembangunan berkelanjutan adalah aktivitas 
pariwisata yang dilaksanakan berdasarkan keseimbangan prinsip Islam, ekologi dan ekonomi. Emil Salim (1992) menjelaskan unsur pembangunan berkelanjutan di Indonesia perlu menumbuhkan sikap kerja saling memerlukan satu dengan yang lain. Kemampuan menserasikan keperluan dengan kemampuan sumber alam, mengembangkan sumber manusia dan konsep pembangunan yang mampu menjawab tatangan.

Sumarwoto (1997) menjelaskan bahwa pariwisata eko adalah industri yang kelangsungannya ditentukan oleh lingkungan. Tanpa lingkungan yang baik tidak mungkin pariwisata eko akan berkembang. Karena itu, pengembangan pariwisata eko harus memperhatikan parorama alam. Sebab dalam industri pariwisata eko, panorama alam yang sebenarnya dijual. Sebagaimana pariwisata syariah alam dan budaya produk ciptaan Allah yang dijual. Pariwisata syariah atau wisata halal tidak hanya diperuntukkan umat muyslim saja tetapi juga diperuntukkan wisatawan non muslim (Fadil, 2017).

Negara di dunia banyak mempromosikan pariwisata eko khususnya di kawasan dilindungi untuk mencapai dua tujuan yaitu konservasi dan memperoleh pendapatan. Perbedaan pariwisata konvensional degan pariwisata eko terletak pada keberlanjutan lingkungan. Pariwisata eko sasarannya lebih diarahkan pada usaha terpeliharanya lingkungan sebagai asset sumber alam. Manajemen pemanfaatan diserasikan dengan budaya setempat dan lingkungan. Pariwisata syariah dapat memberikan kesadaran kepada manusia sebagai khalifah agar dapat mengetahui kebenaran dan kebesaran Nya.

Pariwisata syariah berkelanjutan muncul dan berkembang dikarenakan pariwisata konvensional cenderung mengancam keberlangsungan lingkungan. Tidak sedikit pariwisata konvensinal yang kurang memperhatikan fisik maupun sosial budaya. Perlu disadari dimana permintaan pasar pariwisata telah bergeser pada pariwisata yang lebih menekankan keserasian budaya agama dan lingkungan. Sikap inilah yang perlu diperhatikan dan ditangkap oleh penyelenggara pariwisata.

Indonesia banyak mempunyai tempat-tempat tujuan pariwisata syariah yang menarik. Peraturan perlindungan yang 
tertuang dalam Kepres 32 tahun 1990 tentang pengelolaan kawasan konservasi, yang tidak diperbolehkan mengubah bentuk alam yang ada maupun bangunan dengan unsur budaya setempat. Peraturan ini menjadi peluang pengembangan pariwisata syariah untuk memperluaskan sayapnya.

Peraturan ini berhubungan dengan hasil Konferensi Rio untuk lingkungan, dimana pembangunan yang dilakukan sekarang tidak boleh mendatangkan masalah lingkungan bagi generasi mendatang. Aturan ini juga sejalan dengan isu pariwisata internasional dalam dukumen The World Travel \& Tourism Council tabun 2003. Dimana kegiatan pariwisata perlu sejalan dengan kepentingan ekonomi, masyarakat, sosial budaya agama dan lingkungan.

\section{Metode Penelitian}

Dalam penelitian ini, menggunakan metode biaya perjalanan/ Travel Cost Method (TCM) untuk mengestimasi nilai dari obyek wisata Umbul Pengging. Travel Cost Method (TCM) menggunakan konsep bahwa uang dan waktu yang dihabiskan untuk bepergian ke obyek wisata di luar menunjukkan nilai ekonomi sumber daya pariwisata (Hackett 2000). Travel Cost Method (TCM) perseorangan bersedia membayar biaya perjalanannya ke suatu obyek, dan biaya tersebut berpengaruh terhadap frekuensi kunjungannya.

Regresi linier berganda digunakan untuk mengetahui pengaruh variabel independen penelitian dan fungsi permintaanya. Dalam studi ini, empat variabel independen dimasukkan dalam model yaitu; biaya perjalanan, biaya waktu pengorbanan dan pendapatan serta pendidikan wisatawan.

Model yang dirangcang dalam penelitian ini seperti berikut:

$$
\mathrm{Vij}=\mathrm{a}-\mathrm{b}_{1} \mathrm{X}_{1}+\mathrm{b}_{2} \mathrm{X}_{2}+\mathrm{b}_{3} \mathrm{X}_{3}+\mathrm{b}_{4} \mathrm{X}_{4+\varepsilon}
$$

Dimana:

$\mathrm{Vij}=$ Kunjungan per tahun responden

$\mathrm{X}_{1}=$ Biaya Perjalanan

$\mathrm{X}_{2}=$ persepsi wisata syariah 


$$
\begin{aligned}
& X_{3}=\text { Pendapatan } \\
& X_{4}=\text { Tingkat pendidikan } \\
& a, b=\text { parameter } \\
& \varepsilon=\text { error }
\end{aligned}
$$

\section{Analisis Data Hasil Dan Pembahasan}

Dalam penelitian ini variabel-variabel penentu wisatawan berkunjung di Umbul Pengging dipengaruhi oleh biaya perjalanan dari kediaman wisatawan ke obyek wisata pergi balik, persepsi terhadap wisata syariah yang sedang berkembang sat ini, tingkat pendapatan dan pendidikan wisatawan.

\section{Analisis Kualitatif Responden}

Survei dilakukan di Umbul Pengging dari Juni 2018 sampai Juli 2018. Pertanyaan ditanyakan ke responden tentang lokasi tempat tinggal (alamat), biaya perjalanan individu, jenis kendaraan, persepsi terhadap wisata syariah dan penghasilan bulanan serta tinkat pendidikan wisatawan. Tanggapan responden berkaitan dengan kepuasan, pembenhan/pembangunan, kepentingan kunjungan dan pelestarian. Sebanyak 170 responden yang efektif dikumpulkan. Informasi dari responden yang berwisata di Obyek Umbul Pengging dapat dianalisis seperti berikut:

\section{Profil dan sosioekonomi wisatawan}

Kuesioner digunakan untuk mengumpulkan data langsung dari responden. Informasi sekunder diperoleh dari manajemen pengelola Umbul Pengging dan Dinas Pariwisata Kabupaten Boyolali. Pengambilan sampel dilakukan pada hari libur dan juga hari biasa. Perhatian dilakukan dalam memilih sampel agar tidak terjadi dubel perhitungan dalam satu keluarga.

Profil wisatawan yang berwisata di Umbul Pengging tergambarkan sebagai berikut: 
Jenis Kelamin Responden

Tabel 1. Jenis Kelamin Responden

\begin{tabular}{ccc}
\hline Jenis Kelamin & Kuantitas & Prosentase \\
\hline Perempuan & 107 & $63 \%$ \\
Laki-laki & 63 & $37 \%$ \\
Jumlah & 170 & $100 \%$ \\
\hline
\end{tabular}

Tabel.1. menunjukkan bahwa dari 170 wisatawan ditemui ditempat penelitian dan dipilih secara acak. Seratus prosen responden tersebut menjawab kusioner yang dipersiapkan peneliti. Jenis kelamin responden $63 \%$ perempuan dan $37 \%$ laki-laki. Umbul Pengging perlu memperhatikan faslisitas berenang antara perempuan dan laki-laki. Perlu adanya pemisahan kolam untuk berenang perempuan dan laki-laki sehingga keseganan berenang campur laki-laki dan perempuan dapat dihindari/dihilangkan dan unsur syariah juga diperhatikan karena obyek/tempat berenang putra dan putri dipisahkan.

Usia Responden

Tabel. 2. Usia Responden

\begin{tabular}{lcc}
\hline Usia & Kuantitas & Prosentase \\
\hline Usia 17-30 Tahun & 44 & $26 \%$ \\
Usia 31-43 Tahun & 71 & $41,7 \%$ \\
Usia Diatas 43 Tahun & 55 & $32,3 \%$ \\
Jumlah & $\mathbf{1 7 0}$ & $\mathbf{1 0 0} \%$ \\
\hline
\end{tabular}

Napak pada tabel.2, wisatawan berumur 17-30 tahun sebanyak 26\%, berumur 31-43 tahun sebanyak 41,7 \% dan berumur diatasas 43 tahun 32,3\%. Informasi ini menunjukkan bahwa daerah wisata Umbul Pengging pengunjungnya kebanyak perempuan. Informasi ini memberikan masukan kepada manajemen atau pengelola untuk menyajikan hiburan hiburan yang disukai pada usia -usia tersebut dan kebanyakan wanita. 
Biaya Perjalan Respenden

Tabel. 3. Biaya Perjalanan Responden

\begin{tabular}{lcc}
\hline \multicolumn{1}{c}{ Biaya Perjalanan } & Kuntitas & Prosentase \\
\hline Sampai dengan Rp50.000 & 22 & $13 \%$ \\
Sampai dengan Rp100.000 & 96 & $56 \%$ \\
Diatas Rp100.000 & 52 & $31 \%$ \\
Jumlah & $\mathbf{1 7 0}$ & $\mathbf{1 0 0 \%}$ \\
\hline
\end{tabular}

Biaya perjalanan wisatawan seperti nampak pada tabel.3 sebanyak $13 \%$ pergi balik responden mengeluarkan biaya untuk perjalanan mereka sampai dengan Rp50.000,-. Sebanyak 56\% responden untuk pergi balik ke Umbul Pengging dengan biaya sebanyak sampai dengan Rp100.000,-. Dan sebanyak 31\% mereka untuk pergi balik ke obyek wisata Umbul Pengging dengan pengeluaran biaya perjalanan lebih dari Rp100.000,-. Informasi ini dapat difahami bahwa pengunjung obyek wisata Umbul Pengging sudah dari tempat - tempat yang jauh. Maka untuk menjadikan perhatian perlunya tempat santai-santai yang luas serta tempat parkir yang mewadahi.

\section{Pendapatan Responden}

\section{Tabel. 4. Pendapatan Responden}

\begin{tabular}{lll}
\hline Pendapatan Responden/Bulan & Kuantitas & Prosentase \\
\hline Kurang Dari Rp2.000.000 & 91 & $53,5 \%$ \\
Antara Rp2.000.000- Rp5.000.000 & 64 & $37,6 \%$ \\
Diatas Rp5.000.000 & 15 & $8,9 \%$ \\
Jumlah & $\mathbf{1 7 0}$ & $\mathbf{1 0 0 \%}$ \\
\hline
\end{tabular}

Pendapatan wisatawan sebagaimana yang ditunjukan pada tabel.4 responden berkunjung di Umbul Pengging sebagian besar berpendapatan kurang dari Rp 2.000.000,- artinya mereka masih pada dibawah Upah Mininum yang ditetapkan pemerintah daerah, kelompok ini berjumlah sebanyak 53,5\%. Berpenghasilan sampai Rp5.000.000,- sebanyak 37,6\% dan berpenghasilan diatas 
Rp5.000.000,- sebanyak 8,9\%. Informasi ini memberikan data bahwa obyek wisata Umbul Pengging merupakan obyek wisata yang bersifat inferior untuk wisatawan yang berpenghasilan diatas Rp5.000.000,-. Maka untuk menjadikan obyek ini agar tidak inferior good diperlukan adanya pembenahan/pembangunan obyek.

Pendidikan Responden

Tabel. 5. Pendidikan Responden

\begin{tabular}{lcc}
\hline Pendidikan & Kuantitas & Prosentase \\
\hline Sd - Sltp & 85 & $50 \%$ \\
Slta & 18 & $10,5 \%$ \\
Sarjana & 67 & $39,5 \%$ \\
Jumlah & $\mathbf{1 7 0}$ & $\mathbf{1 0 0} \%$ \\
\hline
\end{tabular}

Pendidikan wisatawan Umbul Pengging seperti yang nampak pada tabel.5 diatas menunjukan bahwa pengunjung didominasi berpendidikan SD dan SLTP sebanyak 50\%. Berpendidikan SLTA 39,5\% dan sarjana 39,5\%. Obyek Umbul Pengging sebenarnya mempunyai potensi sejarah dan budaya yang diperlukan oleh dunia pendidikan. Potensi ini belum digarap oleh pengelola sehingga pengungjung masih banyak berpendidikan SLTA kebawah, serta mereka yang berpendidikan sarjana yang memerlukan layanan sejarah dan budaya mereka tidak mendapatkan layanan pengembangan ilmu pengetahuan tersebut. Maka pengelola perlu pemikiran suatu cara bagaimana adanya guide yang bisa memberikan layanan tetang sejarah Umbul Pengging.

Kepentingan Kunjungan Responden

Tabel. 6. Kepentingan Kunjungan

\begin{tabular}{lcc}
\hline Kepentingan Kunjungan & Kuantitas & Prosentase \\
\hline Olah Raga & 50 & $29,41 \%$ \\
Renang & 116 & $68,23 \%$
\end{tabular}




\begin{tabular}{lrrr}
$\begin{array}{l}\text { Menikmati Keindahan Alam Dan } \\
\text { Lain-Lain }\end{array}$ & 4 & $2,36 \%$ \\
Jumlah & & $\mathbf{1 7 0}$ & $\mathbf{1 0 0 \%}$ \\
\hline
\end{tabular}

Seperti di tabel.6 kepentingan kunjungan para wisatawan didominasi untuk berolah raga sebanyak $29,41 \%$. Khusus berwisata berenang sebanyak $68,23 \%$ dan berwisata dengan menikmati keindahan alam dan lain lain sebanyak 2,36\%. Pada umumnya mereka yang mempunyai kepentingan lain khususnya mereka yang penelitian berkaitan dengan sejarah dan budaya mereka kurang mendapat layanan karena kurangnya layanan pengelola yang faham asal - usul Umbul Pengging maupun sejarah dan budaya semasa kerajaan Mataram Islam. Hubungannya umbul Pengging dan Kraton Kasunaan Surakata Hadiningrat masih berkuasa/ berjaya.

\section{Kepuasan Responden}

Tabel. 7. Kepuasan Responden Terhadap Kesyariahan

\begin{tabular}{lcc}
\hline Kepuasan Responden & Kuantitas & Prosentase \\
\hline Tidak Puas & 12 & $8,23 \%$ \\
Netral & 156 & $91,76 \%$ \\
Puas & 2 & $0,01 \%$ \\
Jumlah & $\mathbf{1 7 0}$ & $\mathbf{1 0 0} \%$ \\
\hline
\end{tabular}

Pada tabel.7 kepuasan responden berkunjung di obyek wisata Umbul Pengging terhadap kesyariahnya mereka menyatakan tidak puas sebanyak $8,23 \%$. Kepuasan yang mereka dapat biasabiasa saja atau netral sebanyak $91,76 \%$. Sedang mereka yang merasa puas ketika berwisata di Umbul Pengging hanya sebanyak $0,01 \%$ saja. 
Tanggapan Responden Berkaitan Pembenahan Wisata Syariah

Tabel. 8. Tanggapan Berkaitan Pembenahan Wisata Syariah

\begin{tabular}{lcc}
\hline Pembenahan & Kuantitas & Prosentase \\
\hline Setuju Tidak Ada Pembenahan Syariah & 13 & $7,65 \%$ \\
Setuju Ada Pembenahan Syariah & 157 & $92,35 \%$ \\
Jumlah & $\mathbf{1 7 0}$ & $\mathbf{1 0 0 \%}$ \\
\hline
\end{tabular}

Tanggapan wisatawan terhadap pembenahan Umbul Pengging menjadi wisata syariah sebanyak $7,65 \%$ mereka menyatakan tidak setuju adanya pembenahan, dan sebanyak $92,35 \%$ menyakan setuju dengan adanya pembenahan Umbul Pengging. Ini perlu menjadi bahan pertimbangan untuk pengelola dalam pembenahan menjadi wisata syariah agar obyek wisata Umbul Pengging tidak lagi menjadi tujuan wisata yang inferior tetapi juga dikenal oleh kalayak yang lebih luas sebagai destinasi wisata syariah.

\section{Tabulasi silang}

Tabulasi silang usia reponden dan pembenahan obyek wisata syariah. Responden yang mendukung pembenahan obyek wisata syariah sebanyak $92,35 \%$ responden. Sebanyak $76,43 \%$ responden berusia 17-30 tahun. Sebanyak 15,92\% responden berusia $31-43$ tahun. Sebanyak $0 \%$ berusia lebih dari 43 tahun. Responden yang tidak mendukung pembenahan obyek wisata sebanyak $7,65 \%$ responden mereka terdiri dari usia 17-30 tahun sebanyak o\%. Usia 31 -43 tahun sebanyak $0 \%$ dan usia lebih dari 43 tahun sebanyak 7,65\%.

Tabel. 9. Tabulsi Silang Usia Responden dengan Pembenahan Obyek Wisata Syariah

\begin{tabular}{|c|c|c|c|c|}
\hline $\begin{array}{l}\text { Sikap } \\
\text { Terhadap } \\
\text { pembenahan } \\
\text { wisata syariah }\end{array}$ & $\begin{array}{c}\text { Usia } \\
17-30 \\
\text { Tahun }\end{array}$ & $\begin{array}{c}\text { Usia } \\
31-43 \\
\text { Tahun }\end{array}$ & $\begin{array}{c}\text { Usia } \\
\text { Diatas } \\
\text { 43 Tahun }\end{array}$ & Jumlah \\
\hline Setuju & $120(76,43 \%)$ & $37(15,92 \%)$ & $0(0 \%)$ & $157(92,35 \%)$ \\
\hline Tidak Setuju & $0(0 \%)$ & $0(0 \%)$ & $13(7,65 \%)$ & $13(7,65 \%)$ \\
\hline Jumlah & $120(76,43 \%)$ & $37(15,92 \%)$ & $13(7,65 \%)$ & $170(100 \%)$ \\
\hline
\end{tabular}


Usia responden berhubungan negatif dengan pembenahan obyek wisata syariah dan berhubungan positif dengan tiada perbaikan seperti ditujukkan oleh tabel diatas. Ini dapat ditafsirkan bahwa generasi muda menghendaki adanya perbaikan - perbaikan sedangkan generasi tua menghendaki adanya kelestarian obyek.

Tabel. 10. Tabulasi Silang Usia dan Kepentingan Kunjungan

\begin{tabular}{lcccc}
\hline $\begin{array}{l}\text { Kepentingan } \\
\text { Kunjungan }\end{array}$ & $\begin{array}{c}\text { Usia } \\
\text { 17-30 Thn }\end{array}$ & $\begin{array}{c}\text { Usia } \\
\text {-43 Thn }\end{array}$ & $\begin{array}{c}\text { Usia } \\
\text { Diatas 43 Thn }\end{array}$ & Jumlah \\
\hline Renang & $95(55,88 \%)$ & $\mathbf{1 1}(6,47 \%)$ & $10(5,88 \%)$ & $116(68,23)$ \\
Olah Raga & 0 & $20(11,76 \%)$ & $30(17,65 \%)$ & $50(29,41 \%)$ \\
$\begin{array}{l}\text { Menikmati } \\
\text { Keindahan }\end{array}$ & & & $4(2,36 \%)$ & $4(2,36 \%)$ \\
$\begin{array}{l}\text { Alam dll } \\
\text { Jumlah }\end{array}$ & & & & \\
\hline
\end{tabular}

Kepentingan kunjungan dilihat dari segi usia nampak bawa mereka yang tujuannya untuk berenang sebanyak $68,23 \%$. Olah Raga tenis sebanyak 29,41\% dan berwisata menikmati keindahan alam dan lain-lain kepentingan sebanyak 2,36\%. Berdasarkan usia mereka bertujuan berenang mayoritas usia remaja antara 17 -30 tahun sebanyak 55,88\%. Renang dan tenis sebanyak 18,23\% terbagi atas renang 6,47\% dan tenis $17,65 \%$. Mereka yang usia 43 tahun keatas sebanyak $25,89 \%$, mereka mempuyai kepentingan sebanyak 5,88 \% berenang, sebanyak $17,65 \%$ tenis dan sebanyak 2,36\% berwisata menikmati keindahan alam dan keperluan lain.

Dari segi pendapatan dan kepuasan yang diperoleh wisatawan nampak bahwa mereka terbagi dari tiga kelompok pendapatan, sebanyak $0,01 \%$ kelompok berpenghasilan kurang dari 2 juta sebulan. Sebanyak 33,53\% berpenghasilan $2-5$ juta sebulan dan sebanyak $66,46 \%$ berpenghasilan diatas 5 juta sebulan. Kepuasan yang didapat wisatawan atas wisatanya di Umbul Penggging terbagi pada mereka yang merasa tidak puas sebanyak $0 \%$ responden dengan penghasilan kurang dari 2 juta sebulan. Sebanyak 0\% berpenghasilan 2juta - 5 juta sebulan dan 8,23\% berpenghasilan diatas 5 juta sebulan. Mereka yang menyatakan netral sebanyak $0 \%$ berpenghasilan kurang dari 2 juta sebulan. 
Sebanyak 33,53\% berpenghasilan antara 2juta - 5 juta sebulan dan $58,23 \%$ berpenghasilan diatas 5 juta sebulan. Selanjutnya mereka yang menyatakan puas sebanyak $0,01 \%$ berpendapatan kurang dari 2 juta sebulan, $0 \%$ berpenghasilan 2 juta -5 juta sebulan dan sebanyak $0 \%$ berpenghasilan diatas 5 juta sebulan.

Tabel. 11. Tabulasi Silang Kepuasan Wisata Syariah dan Kelompok Penghasilan

\begin{tabular}{llllr}
\hline Kepuasan & $\begin{array}{c}\text { Penhasilan } \\
<\mathbf{2} \text { juta/ } \\
\text { bulan }\end{array}$ & $\begin{array}{c}\text { Penghasilan } \\
\mathbf{2} \text { juta }-\mathbf{5} \\
\text { juta/bulan }\end{array}$ & $\begin{array}{c}\text { Penghasilan } \\
>\mathbf{5} \text { juta/ } \\
\text { bulan }\end{array}$ & Jumlah \\
\hline Tidak puas & $0(0 \%)$ & $0(0 \%)$ & $\mathbf{1 2}(8,23 \%)$ & $12(8,23 \%)$ \\
Netral & $0(0 \%)$ & $57(33,53 \%)$ & $99(58,23 \%)$ & $\mathbf{1 5 6}(91,76 \%)$ \\
Puas & $2(0,01 \%)$ & $0(0 \%)$ & $0(0 \%)$ & $2(0,01 \%)$ \\
Jumlah & $\mathbf{2 ( 0 , 0 1 )}$ & $\mathbf{5 7}(33,53)$ & $\mathbf{1 1 1}(\mathbf{6 6}, \mathbf{4 6})$ & $\mathbf{1 7 0}(\mathbf{1 0 0} \%)$ \\
\hline
\end{tabular}

Penggunaanairumbuldapat digunakanberbagaipenggunaan misal dilestrarikan sebagai kolam renang, untuk wisata air syariah atau juga dapat dikomersialkan menjadi industri air minum yang dikelola oleh lembaga atau badan usaha. Tanggapan masyarakat terhadap pengelolaan air umbul ada berbagai kegunaan. Dilestarikan sebagai umbul kolam renang syariah ada juga yang ingin dikomersialkan atau menjadi air minum yang dikelola oleh badan usaha. Tabel.12 memperlihatkan tanggapan wisatawan terhadap wisata Syariah kovensional dan campuran adalah seperti berikut:

Tabel. 12. Tabulasi Silang Wisata Syariah, Konvensinal dan Campuran Dengan Usia Responden

\begin{tabular}{|c|c|c|c|c|}
\hline $\begin{array}{c}\text { Pilihan } \\
\text { Responden }\end{array}$ & $\begin{array}{c}\text { Usia } \\
17-30 \text { thn }\end{array}$ & $\begin{array}{c}\text { Usia } \\
31-43 \text { thn }\end{array}$ & $\begin{array}{c}\text { Usia } \\
\text { diatas } 43 \text { thn }\end{array}$ & Jumlah \\
\hline Wisata syariah & $90(52,93 \%)$ & $50(29,41 \%)$ & $10(5,90 \%)$ & $150(88,24 \%)$ \\
\hline $50 \%$ Konvensinal & $0(0 \%)$ & $15(8,82 \%)$ & $0(0 \%)$ & $15(8,82 \%)$ \\
\hline 100\% Campuran & $5(2,94 \%)$ & $0(0 \%)$ & $0(0 \%)$ & $5(2,94 \%)$ \\
\hline Jumlah & $95(55,87 \%)$ & $65(38,23 \%)$ & $10(5,90 \%)$ & $170(100 \%)$ \\
\hline
\end{tabular}

Tanggapan wisatawan terhadap isu perubahan menjadi wisata syariah, konvensional, campuran berdasarkan usia tampak 
bahwa sebanyak $88,24 \%$ setuju menjadi wisata syariah yang terdiri dari usia 17-30 tahun sebanyak 52,93\%, usia 31 -43 tahun sebanyak 29,42\%, usia diatas 43 tahun sebanyak 5,9\%. Memberi tanggapan separuh konvensional mereka yang berusia antara 31 - 43 tahun sbanyak $8,82 \%$. Dan yang menghendaki semua konvensional mereka yang berusia 17 - 30 tahun sebanyak $2,94 \%$.

Tabel. 13. Tabulasi Silang Wisata Syariah, Konvensional dan Campuran Dengan Penghasilan Responden

\begin{tabular}{llllc}
\hline \multicolumn{1}{c}{$\begin{array}{c}\text { Pilihan } \\
\text { Responden }\end{array}$} & $\begin{array}{c}\text { Penhasilan } \\
\text { < 2 Juta/Bln }\end{array}$ & $\begin{array}{l}\text { Penghasilan } \\
\text { 2-5 Juta/Bln }\end{array}$ & $\begin{array}{l}\text { Penghasilan } \\
\text { > 5 Juta/Bln }\end{array}$ & Jumlah \\
\hline Wisata Syariah & 130(76,47\%) & $\mathbf{8}(4,70 \%)$ & $15(8,83 \%)$ & $153(90 \%)$ \\
50\%Konvensional & 0(0\%) & $13(7,65 \%)$ & $0(0 \%)$ & $13(7,65 \%)$ \\
100\%Campuran & $4(2,35 \%)$ & $0(0 \%)$ & $0(0 \%)$ & $4(2,35)$ \\
Jumlah & $\mathbf{1 3 4 ( 7 8 , 8 2 \% )}$ & $\mathbf{2 1 ( 1 2 , 3 5 \% )}$ & $\mathbf{1 5}(\mathbf{8 , 8 3 \% )}$ & $\mathbf{1 7 0}(\mathbf{1 0 0 \% )}$ \\
\hline
\end{tabular}

Tanggapan responden berkaitan isu wisata syariah, konvensional dan campuran sebanyak $90 \%$ menghendaki sebagai wisata air syariah yang terbagi pada pendapatan kurang dari 2 juta sebanyak $76,47 \%$, berpenghasilan antara 2 juta - 5juta sebanyak $7,65 \%$. Serta yang setuju semua campuran sebanyak $2,35 \%$ mereka yang berpenghasilan diatas 5 juta.

Tabel. 14. Tabulasi Silang Antara Wisata Syariah, Konvensional, Campuran Dengan Pendidikan Responden

\begin{tabular}{|c|c|c|c|c|}
\hline $\begin{array}{c}\text { Pilihan } \\
\text { Responden }\end{array}$ & $\begin{array}{l}\text { Pendidik } \\
\text { SD - SLTP }\end{array}$ & $\begin{array}{c}\text { Pendidikan } \\
\text { SLTA }\end{array}$ & $\begin{array}{c}\text { Pendikan } \\
\text { S1 S2 S3 }\end{array}$ & $\mathbf{J u}$ \\
\hline Wisata Syariah & $10(5,9 \%)$ & $20(11,75 \%)$ & $125(73,52 \%)$ & 155 \\
\hline $50 \%$ Konvensional & $10(5,88 \%)$ & $0(0 \%)$ & $0(0 \%)$ & $10(5,88 \%)$ \\
\hline 100\% Campuran & $0(0 \%)$ & $5(2,95 \%)$ & $0(0 \%)$ & $5(2,95 \%)$ \\
\hline Jumlah & $20(11,78 \%)$ & $25(14,70 \%)$ & $125(73,52 \%)$ & $170(100 \%)$ \\
\hline
\end{tabular}

Dari isu wisata syariah, konvensional dan campuran dilihat dari tingkat pendidikan wisatawan atau responden, sebanyak 91,17\% menghendaki sebagai obyek wisata air syariah mereka terdiri dari mereka perpendidikan S1 S2 S3 sebanyak 73,52\%, SLTA sebanyak 11,75\%, SLTP sebanyak 5,9\%. Yang berkeinginan konvensional sebanyak $5,88 \%$ responden, terdiri dari mereka 
berpendidikan SD_SLTP dan yang menghendaki seratus persen campuran sebanyak $2,95 \%$ mereka berpendidikan SLTA.

Dari data hasil survei dianalisis dengan regresi berganda diperoleh persamaan sebagai berikut:

$$
\begin{aligned}
\mathrm{Vij}= & 85,867-0,0251 \mathrm{X}_{1}+0,001 \mathrm{X}_{2}-0,007 \mathrm{X}_{3}+0,004 \mathrm{X}_{4} \\
& (7,06)^{* *}(-1,95)^{* *}(0,00)(-0,009)^{* * *}(1,295)^{* * *} \\
& \mathrm{R}^{2}=0,237 \\
& \mathrm{~F}=0,6
\end{aligned}
$$

Nilai dalam kurung adalah T-test

** = Signifikan pada uji 5\%

$* * *=$ Signifikan pada uji $1 \%$

$\mathrm{R}$ Square, $\mathrm{R}^{2}=0,237$, Adjusted $\mathrm{R}^{2}=0,219$

Koefisien determinasi, $\mathrm{R}^{2}$ mengukur proporsi dari variasi variabel dependen yang dijelaskan oleh variabel independen. Sebuah $\mathrm{R}^{2}$ yang lebih tinggi akan berarti bahwa garis persamaan $\mathrm{Y}$ dihitung cocok dekat dengan titik data (Ahmad 1994).

Namun, $\mathbf{R}^{2}$ untuk studi itu ditemukan rendah sebesar $(0$. 237 ), dengan hanya $23,7 \%$ yang menjelaskan kunjungan per tahun oleh responden. Hal ini mungkin karena terbatasnya jumlah variabel independen yang digunakan dalam model. Mungkin ada variabel-variabel lain yang dapat mempengaruhi keputusan kunjungan ke destinasi wisata syariah yang tidak dimasukkan dalam model. Setiaji mengatakan nilai $\mathrm{R}^{2}=0,2$ atau 0,3 untuk survai datanya bersifat cross section sudah cukup baik model yang dibentuk (Setiaji 2009). Ini juga menunjukkan jumlah anggota sampel yang besar karena semakin besar ukuran sampel maka nilai $\mathrm{R}^{2}$ cenderung makin kecil.

T-test pada interval kepercayaan 95\% (t-tabel nilai 1,96) dipergunakan untuk menguji signifikansi statistik dari koefisien regresi. Setiap nilai t-dihitung yang lebih besar dari nilai t-tabel berarti bahwa variabel tersebut memainkan peran penting dalam menentukan variabel dependen (Mohd Azmi 1996).

Dalam studi ini, ditemukan bahwa biaya perjalanan dan pendapatan serta pendidikan signifikan sementara biaya 
pengorbanan persepsi wisata syariah ditemukan tidak signifikan. Tanda-tanda negatif dari biaya perjalanan dan pendapatan tersirat bahwa variable-variabel tersebut berbanding terbalik dengan variabel dependen. Koefisien beta untuk $\mathrm{X}_{1}$ tersirat bahwa kenaikan Rp1000 dalam biaya perjalan akan mengurangi kunjungan sebayak 2,51 kunjungan per tahun.

Hubungan negatif dari biaya perjalanan konsisten dengan teori permintaan dimana kenaikan harga mengurangi kuantitas. Hal ini menunjukkan bahwa responden dari lokasi lebih yang lebih jauh domisilinya akan semakin sekikit kesempatan untuk berkunjung karena mereka harus menanggung biaya lebih tinggi perjalanan ke Umbul Pengging. Harga meningkat (P) maka jumlah yang diminta $(\mathrm{Q})$ turun.

Hubungan terbalik pendapatan dan berkunjung menunjukkan bahwa Umbul Pengging adalah barang inferior. Seiring dengan peningkatan penghasilan bulanan, pengunjung melakukan kunjungan yang lebih sedikit untuk Umbul Pengging. Hal ini mungkin disebabkan fakta bahwa pendapatan bulanan ratarata pengunjung untuk Umbul Pengging Rp3,9 juta. Peningkatan pendapatan dapat menggeser permintaan oleh para pengunjung ke obyek wisata syariah lebih menarik yang memiliki fasilitas yang dapat memenuhi kebutuhan mereka karena pengunjung melakukan substitusi antar destinasi (Ward \& Beal 2000).

Pendidikan wisatawan menunjukan hubungan yang posif memberikan inormasi adanya petujuk bahwa semakin tinggi pendidikan wisatawan semakin berminat berkunjung ke destinsi tersebut. Berkemungkinan ia ingin tahun sejarah keberadaan umbul tersebut, ini perlu pemikiran perlu tidaknya guide yang faham akan sejarah tempat tersebut dan signifikan (Weber 2006).

Perhitungan nilai ekonomi destinasi obyekfungsi permintaan ditentukan dan diperkirakan. Untuk penelitian ini, konsep surplus konsumen digunakan, seperti yang ditunjukkan oleh luas area di bawah kurva permintaan diatas garis harga. Dengan asumsi ceteris paribus (variabel lainnya adalah konstan), kecuali untuk biaya perjalanan. Fungsi permintaan ditunjukkan seperti di bawah ini: 


$$
\mathrm{Vij}=-0,0251 \mathrm{X}_{1}+85,867
$$

Ukuran surplus konsumen dapat diperkirakan dengan mengambil integral dari fungsi permintaan dalam Persamaan (2). Surplus konsumen diperkirakan Rp504 juta per tahun dengan biaya nol. Untuk mendapatkan manfaat individu wisata syariah Umbul Penggging, surplus konsumen rata-rata untuk setiap kunjungan, di mana Rp504 dibagi dengan kunjungan maksimum. Ini sama dengan Rp5,8 juta/orang/kunjungan/tahun.

Untuk memperkirakan nilai ekonomi total Umbul Pengging, surplus konsumen / orang / kunjungan / tahun kemudian dikalikan dengan jumlah total pengunjung per tahun (satu pengunjung berkunjung satu kali satu tahun). Pada tahun 2018, total kunjungan Umbul Pengging dari sampel, rata-rata kunjungan per orang diperkirakan 1,48 kunjungi / orang. Oleh karena itu rata-rata pengunjung untuk Umbul Pengging pada tahun 2018 diperoleh dengan membagi total kunjungan 2018 dibagi rata-rata kujungan tahun tersebut. Nilai ekonomi total Umbul Pengging sebagai destinasi pariwisata syariah diperkirakan sebanyak Rp44.565 juta untuk tahun 2018.

\section{Manfaat Ekonomi Pariwisata}

Manfaat Wisata syariah yang mempunyai ciri bentuk bukan pasar fungsi permintaannya tidak bisa diestimasi dengan model estimasi biasa. Secara teori model penilaiannya dengan mempergunakan teori konsumen dan kriteria ekonomi kesejahteraan. Model estimasi yang bisa digunakan dengan model biaya perjalanan (Cesario, 1976); (Jamal et al. 2004). Metode biaya perjalanan yang pertama dan banyak dipergunakan untuk manfaat wisata. Pertama dimulai dari surat Harold Hotelling untuk ketua pengelola Taman Negara Amerika Serikat tahun 1947, dan secara resmi diperkenalkan di tulisan Wood dan Trice (1958) serta Clason dan Knetsch (1966). Metode biaya perjalanan kebanyakan digunakan dalam beberapa penelitian di Malaysia. Diantaranya penelitian tetang peluang-peluang wisatawan Pulau di Langkawi (Ahmad, 1994). 
Wisata luar dibagi menjadi beberapa jenis, salah satu diantaranya wisata berdasarkan sumber alam. Dipandang dari aspek ekonomi, manfaat wisata alam berbentuk nilai penggunaan tidak langsung. Tetapi dalam suatu kasus dapat dianggap sebagai nilai penggunaan langsung seperti aktivitas memancing atau perburuan (Kumari, 1994).

Wisata alam, seperti pantai, sungai, pegunungan, rawa-rawa, umbul mempunyai banyak fungsi khususnya memberikan peluang wisata syariah kepada manusia. Umbul dapat memberikan jasa layanan wisata yang meliputi dari kesenangan pasif dan pasif serta menantang, seperti melihat kehidupan liar dan melihat burung, mengamati ikan rafting disepanjang sungai sekitar umbul.

Sumber-sumber lingkungan dan sumber asli lain layanan wisata oleh rawa-rawa dan air mempunyai ciri penting (Freeman 1992); (Hanley dan Spash 1995); (Sinden dan Worrel 1978). Pertama ciri terpenting nilai ekonomi layanan ini sangat tergantung sifat ekosistem dan cara pengelolaannya. Pengunjung dan wisatawan yang datang ke tempat ini dikarenakan karena adanya faktor keunikan, daya tarik landskip, spesies flora dan fauna (biodiversity) mengeplotasi nilai-nilai keislaman sehingga tempat tersebut perlu dilindungi. Perlindungan tersebut ditentukan oleh kualitas dan kuantitas air, udara dan tanah di tempat tersebut.

Sekiranya tanah umbul tidak dilingdungi, kebijakan manajemen penebangan pohon, penangkapan ikan dilakukan secara komersial, persaingan hak penggunaan tanah dan air, intensitasnya tidak terkontol maka dapat menyebabkan pencemaran lingkungan. Pengelolaan ekosistem tanah umbul dan kebijakan dalam pengelolaan sumber akan mempengaruhi potensi umbul sebagai komoditi ekonomi. Maka penting untuk mengetahui bagaimana ciri-ciri ekosistem dan kebijakan pengelolaan yang memberikan pengaruh terhadap nilai wisata tanah umbul tersebut.

Kedua tanah umbul memberikan layanan jasa wisata gratis yang dilindungi, walau dengan biaya tiket masuk yang juga dipungut. Lazimnya nilai tiket masuk yang diberlakukan terlalu rendah dan tidak memberikan beban biaya terhadap permintaan. Keadaan ini kedua-duanya tidak terdapat variasi atau hanya sedikit 
variasi dalam data harga yang diperlukan untuk estimasi fungsi permintaan secara ekonometrik. Meski berkaitan dengan estimasi permintaan, ia tidak menggambarkan kesedian membayar untuk memperoleh layanan jasa wisata tersebut, maka pendekatan alternatif diperlukan dalam menilai daerah wisata syariah.

Ketiga jasa layanan wisata tanah umbul yang dilindungi ini unik, artinya jasa yang diberikan tidak dapat dipindahkan ke obyek lain. Setiap wisatawan perlu berwisata ke obyek tersebut untuk mendapatkan jasa layanan tersebut. Kunjungan ini behubungan dengan biaya dan persepsi terhadap destinasi wisata syariah dimana biaya perjalanan antara wisatawan satu dengan yang lain berbeda. Ciri ini penting sebagai langkah untuk menjawab ketiadaan variasi harga untuk memperoleh maanfaat berwisata ke obyek tersebut. Perbedaan biaya perjalan dapat digunakan untuk mengestimasi fungsi permintaan secara ekonometrik. Respon wisatawan termasuk bukan pengunjung merupankan dasar untuk menghitung nilai jasa wisata dan perubahan kualitas kesyariahan tempat tersebut. Perubahan kualitas tempat tersebut disebabkan oleh kebijakan pengelolaan sumber atau tingkat penggunaan pengunjung.

\section{Kesimpulan}

Penelitian menunjukkan bahwa Umbul Pengging adalah obyek populer untuk wisata luar di Boyolali JawaTengah tetapi inferior kesyarianhannya dan untuk wisatawan berpenghasilan diatas 5 juta. Nilai ini bersarkan estimasi nilai minimal. Informasi ini berguna untuk lembaga manajemen mungkin perlu tahu apakah fasilitas dan layanan wisata syariah yang diberikan memiliki manfaat para pengunjung. Ukuran surplus konsumen menunjukkan nilai dari Umbul Pengging untuk para pengunjung. Peningkatan layanan destinasi perlu menjadi prioritas manajemen sehingga kepuasan pengunjung meningkat. Penyajian peningkatan kepuasan dapat berefek menarik pengunjung baru.

Penelitian ini fokus pada metode biaya perjalanan dengan tambahan empat variabel lainnya. Penelitian ini juga menunjukkan 
bahwa pendapatan dapat mengubah permintaan dari obyek wisata baik secara positif maupun negatif. Kenaikan pendapatan pengunjung bisa jadi mengubah obyek berwisata yang menjadi pilihan. Untuk manajemen perbaikan kenyamanan wisata syariah diperlukan. Pendidikan menunjukkan hubungan yang positif perlu menjadi pemikiran kepada pihak manajemen perlu tidaknya guide yang faham sejarah keberadaan Umbul Pengging yang dapat memberikan informasi kepada pengunjung. Disarankan variabel lain dapat ditambahan dalam analisis regresi untuk membangun model yang lebih baik. 


\section{Daftar Pustaka}

Aan Jaelani, 2017. Industri Wisata Halal di Indonesia Potensi dan Prospek. MPRA. Online at https://mpra.ub,uni-menchen. de/76237/MPRAS Paper no.76237.

Addin Maulana, 2016. Pengaruh Kunjungan Wisatawan Mancanegara Dan Perjalan Wisatawan Nusantara Terhadap Penyerapan Tenaga Kerja Sektor Pariwisata Indonesia. Jurnal Kepariwisataan Indonesia. Vol.11. N0.1 Juni 2016. ISSN 1907-9419.

Ade Ela Pratiwi, 2016. Analisis Pasar Pariwisata Syariah di Kota Yogyakarta. Jurnal Media Wisata.Vol.14.No.1.

Alisjahbana A.S, 2000. Pengengbangan Pariwisata Daerah Memasuki Era Otonomi Daerah dan Desentralisasi. Makalah pada Seminar Persatuan Hotel dan Restauran Indonesia (PHRI). Bandung

Ahmad, S. 1994. Demand for and value of outdoor recreation in Langkawi by Domestic Visitors. Thesis for Doctoral of Philosophy, UPM, Serdang. Pp. 279.

Cooper C., Fletcher J., Gilbert D., Wanhill S., 1996. Tourism Principles \& Practice, Longman, London.

Cesario, F. J. 1976. Value of time in recreation benefit studies. Jurnal Land Economics 52 (1): 32-41.

Clawson M and Knetch J, 1966. Economic of Outdoor Rereation. Dlm Hanley, Nick \& Spansh,Clive. L (Pnyt). Cost-Benefit Analysis and the Environment. Edward Elgar Publishing Limited. Dan Hukum Al-Ahkam.Vol.2.No.1.

Fadil Amin Al Hasan, 2017. Penyelenggaraan Pariwisata Halal di Indonesia.(Analisis Fatwa DSN-MUI tentang Pedoman Penyelenggaraan Pariwisata Berdasarkan Prinsip Syariah). Jurnal Ilmu Syariah

Damanik J., Weber HF., 2006. Perencanaan Ekowisata, dari Teori ke Aplikasi, Andi Offset, Yogjakarta. 
Departemen Kebudayaan dan Pariwisata. 2005 Rencana Strategis Pembangunan dan kepariwisataan Nasional 2005-2009. DepBudPar Indonesia.

Elliot, P, Reed, R. \& Franklin, J. 2001. The Valuation of National Parks - Analysis, Methodology and Reliability; Paper presented at The Inaugural IASCP Pacific Regional Meeting, Brisbane, September. Pp.16.

(http://dlc.dlib.indiana.edu/archive/00001037/00/El 1 iott2001. pdf).

Emil Salim., 1992. Dlm. Pembangunan Berkelanjutan Mencari Format Politik. Yayasan EPES. Jakarta. Gramedia Pustaka Utama.

Freeman, A.M. 1994. The Measurement of Environmental and Resources Value: theori and methods. Woshington, D.C: Resources for the Future.

Hackett, S.C. 2000. The recreational Economic Value of the Eastern Trinity Alps Wilderness..http://www.humboldt. edu/ envecon/econ_423/trinityAlps.html).

Helln Angga Devy, 2017. Pengembangan Obyek Wisata Dan Daya Tarik Wisata Alam Sebagai Daerah Tujuan Wisata Di Kabupaten Karanganyar. Jurnal Sosiologi DILEMA, Vol.32. No. 1. 2017. ISSN 0215/9635

Jamal Othman, Basri Abdul Talib, Redzuan Othman, 2004. Nilai Ekonomi Khidmat Rekreasi Taman Pertanian Malaysia, Shah Alam. IJMS. 11 (1): 165-179.

Keraf, A.S., 2006. Etika Lingkungan, Kompas, Jakarta

Kurniawan Gilang Widagdyo, 2015. Analisis Pasar Pariwisata Halal Indonesia. The Juoirnal of Tauhidinimics. Vol 1.N0.1 73-80

Kumari Kanta, 1994. Sustainable Forest Management in Peninsular Malysia: Towards Total a Total Ekonomic Valuation Approach. East Anglia University. DX1802. 
Lucky Setiawan, Ida Ayu Suryaningsih 2016. Karakteristik Dan Persepsi Wisatawan Terhadap Daya Tarik Wisata Pantai di Kota Pariaman Sumatera Barat. Jurnal Distinasi Pariwisata. Vol. 4. No.1.2016.ISSN 2338-8811.

Loomis, J.B. Juan Marcos Gondalez, Armando Gonzalez-Caban, 2007. Spatial Limits of the TCM: Island Effects. JEL: Agricultural and Natural Resource Economics.

Mc Nally, R. \& Mohd. Shawahid, O. 2002. Environmental Economics: A Practical Guide. WWF, UPM Selangor. Pp. 123. Publishers B.V.11:677-722.

McConnell, K.E.1985. The economics of outdoor recreation. Dlm. Kneese, A.V. \& Sweeney. J.L.(Penyt) Handbooks of natural resource and energy economics, Elsevier Science

Mohd Azmi, M. I. 1996. Demand for Recreation at Lentang Forest Recreation Area. Bachelor Degree Thesis. Universiti Pertanian Malaysia. Pp. 98.

Rahmi Syahriah, 2014. Pariwisata Berbasis Syariah (Telaah Makna Sara dan Derivasinya Dalam Al-Qur'an). Jurnal Human Falah.Vol.1.No.2

Setiaji, Bambang 2009, Jalan Mudab ke Analisis Kuantitatif, Surakarta: Al-es'af Press

Safri M., 2003. Kajian Pengelolaan Taman Nasional Kerinci Seblat Dalam Perspektif Ekonomi Lingkungan, Disertasi Doktor IPB Bogor

Santoso S.P. 2002. Pengembangan Pariwisata Indonesia. Kontibusi dalam Kolom Pakar Pinter, dalam talian http://www.kolom. pacific, net,id/ind

Soekadijo R.G., 1996. Anatomi Pariwisata, Gramedia,Jakarta

Soemarwoto O., 1997. Ekologi Lingkungan Hidup dan Pembangunan,Djambatan, Jakarta

Yoeti O.A., 1996. Pengantar Ilmu Pariwisata, Angkasa, Bandung 
Ward, F. A. \& Beal, D. 2000. Valuing Nature with Travel Cost Methods. Massachusetts. Edward Elgar Publishing.

Wood, S. And Trice, A. 1958. Measurement of Recreation Benefits. Land Economics, 34: 195-207. 